\section{Growth and Interior Performance of Poinsettia in Media Containing Composted Cotton Burrs}

\author{
Yin-Tung Wang' and Thomas M. Blessington ${ }^{2}$ \\ Texas A\&M University Agricultural Research and Extension Center, \\ 2415 East Highway 83, Weslaco, TX 78596 \\ Additional index words. Euphorbia pulcherrima
}

Abstract. Rooted cuttings of Euphorbia pulcherrima Willd. ex Klotzsch CV. Gutbier V-14 Glory were planted in 2-liter containers with growth media having $0 \%$ to $75 \%$ composted cotton burrs (CCB) in combination with sphagnum peat and/or composted pine bark. Leachates from media with $50 \%$ or more CCB had higher initial electrical conductance (EC) (3.7 to $\left.4.0 \mathrm{dS} \cdot \mathrm{m}^{-1}\right)$ than that from media with $25 \%$ or no CCB $(2.8$ to $\left.3.0 \mathrm{dS} \cdot \mathrm{m}^{-1}\right) 2$ weeks after planting. The differences in leachate EC declined after an additional 9 weeks. Media containing CCB produced slightly shorter and narrower plants with $10 \%$ smaller inflorescences and less dry weight than plants grown in a medium consisting of equal volumes of peatmoss and bark. Number of branches and bracts, days to bloom, and plant grade after 30 days under $15 \mu \mathrm{mol} \cdot \mathrm{s}^{-1} \cdot \mathrm{m}^{-2}$ photosynthetic photon flux were unaffected by media.

Most potted ornamental plants are produced in artificial growing media without mineral soil. These media are usually a mixture of peatmoss, bark, perlite, and/or vermiculite. Sawdust and other porous organic and inorganic materials having good water retention and nutrient-holding properties are also used. The composition of growing media has been shown to affect plant growth, sometimes being a determinant factor between profit and crop loss (Sheehan and Tjia, 1976).

Peatmoss has been traditionally used as an important ingredient in preparing potting media because of its high water-holding and cation exchange capacities. Due to the high cost and unstable supply of peatmoss, other substitute materials have been studied. Medium composition was previously found to affect the growth of poinsettia (Blessington et al., 1981; Fonteno et al., 1981) and may influence the performance of pot-grown plants under interior conditions (Wang and Sauls, 1988)

Cotton burrs is a waste product generated in large quantities by the cotton industry that must be disposed of properly to reduce environmental or pest problems. Since cotton burrs absorb water, they may have potential, after being composted, for use in media for producing potted flowering plants. The objective of this study was to determine the effect of composted cotton burrs in media on

Received for publication 5 May 1989. Poinsettia cuttings were donated by Paul Ecke Poinsettias, Encinitas, Calif. Composted cotton burrs and partial financial support were provided by Back to Earth Resources, Dallas, Texas. The cost of publishing this paper was defrayed in part by the payment of page charges. Under postal regulations, this paper therefore must be hereby marked advertisement solely to indicate this fact.

${ }^{1}$ Assistant Professor.

${ }^{2}$ Professor and Center Director. chemical properties of the media and on greenhouse production and interior performance of poinsettia.

Rooted poinsettia cuttings with four to five leaves were obtained from a commercial source and planted one per $16.4-\mathrm{cm}$ white plastic pot (2 liters) on 15 Sept. 1988, The ingredients of the growing media included Canadian sphagnum peat, composted pine bark $(<12 \mathrm{~mm})$, and composted cotton burrs (CCB). The CCB was used in conjunction with one or two of the above ingredients (Table 1). A medium with equal volumes of composted pine bark and peatmoss was used as the control. Ingredients for each medium were blended for 2 $\min$ in a rotary mixer. Finely ground dolomitic lime and Micromax (a micronutrient source, W.R. Grace and Co., Fogelsville, Pa.) were added to media at rates of 4.0 and $1.0 \mathrm{~kg} \cdot \mathrm{m}^{-3}$, respectively. A wetting agent (Aqua-Grow, Aquatrols Corp. of America, Pennsauken, N.J.) was added to all media at the manufacturer's recommended rate. Plants were grown in a greenhouse with a maximum photosynthetic photon flux (PPF) of $720 \mu \mathrm{mol} \cdot \mathrm{s}^{-1} \cdot \mathrm{m}^{-2}$, pinched to $\approx 7.5 \mathrm{~cm}$ on 30 Sept., and sprayed with paclobutrazol at $50 \mathrm{ppm}$ on 16 Oct.; the medium surface was covered with a layer of polyethylene to prevent contamination. was the control.
Water containing 24N-3.4P-12.3K soluble fertilizer (W.R. Grace and Co.) at $1.0 \mathrm{~g} \cdot$ liter $^{-1}$ was used for irrigation until 1 Nov., at which time fertilizer rate was increased to $1.5 \mathrm{~g} 20 \mathrm{~N}$ 8.6P-16.6K/liter. Ammonium molybdate was added to fertigation water at $3.7 \mathrm{mg} \cdot \mathrm{liter}^{-1}$ to ensure adequate Mo supply (Hammer and Bailey, 1987). All fertilization was discontinued after 27 Nov. Plants were irrigated two or three times a week, depending on weather conditions, and never showed any symptoms of water stress. The maximum day and minimum night air temperatures during the period of active color development were 31 and $15 \mathrm{C}$, respectively.

Leachate samples were taken from each pot at 2, 8, and 11 weeks after potting by the use of the pour-through technique (Yeager et al., 1983; Wright, 1986). Pots were watered in the late afternoon with fertilizer solution, except on the last collection date, when water without fertilizer was used. The following morning, a sufficient amount of water with an electrical conductance (EC) $<0.01 \mathrm{dS} \cdot \mathrm{m}^{-1}$ was evenly added to the medium surface to collect 35 to $50 \mathrm{ml}$ of leachate. Leachates were placed in the laboratory overnight to equilibrate with room temperature (24 to 26C) and then analyzed for EC (indicative of total soluble salts) and $\mathrm{pH}$.

Bloom date was recorded for each plant as pollen started to shed from a cyathium. Number of branches was counted and plant height (pot rim to the tallest point) and width (average of two measurements made at perpendicular angles), as well as width of the inflorescence, number of large and small bracts, and number of leaves on the tallest shoot were recorded.

Plants were removed into postharvest rooms held between 18 and $23 \mathrm{C}$ and with a 12-hr photoperiod of $15 \mu \mathrm{mol} \cdot \mathrm{s}^{-1} \cdot \mathrm{m}^{-2} \mathrm{PPF}$ (from cool-white fluorescent tubes) at plant level to simulate a common interior environment. Relative humidity was not controlled, but was monitored and varied between $50 \%$ and $72 \%$. Plants were evaluated after 30 days for number of abscised bracts and leaves and overall plant grade. Shoots then were severed at the soil line, dried for $72 \mathrm{hr}$ at $70 \mathrm{C}$ in a forcedair oven, and dry weights recorded.

There was one plant per pot as an experimental unit replicated 8 times in a randomized complete-block design. Data were subjected to analysis of variance using SAS

Table 1. Electrical conductance and $\mathrm{pH}$ of medium leachate as affected by medium composition.

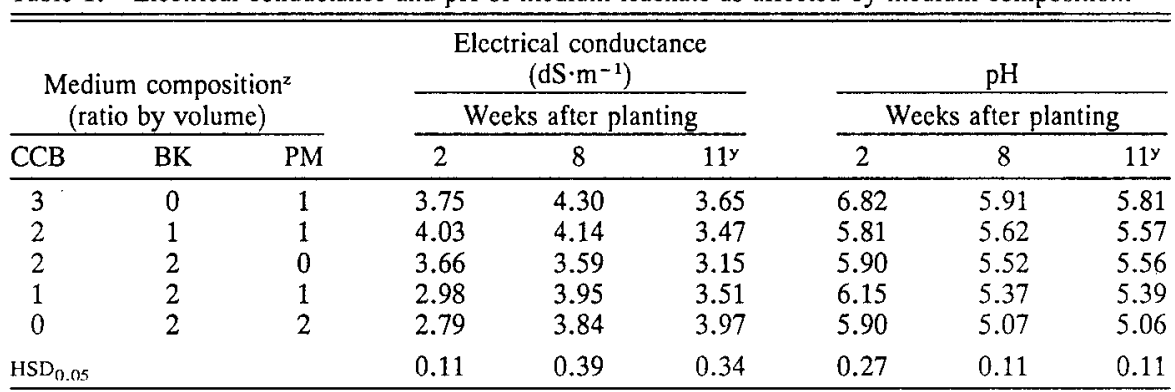

${ }^{z} \mathrm{CCB}=$ composted cotton burrs, $\mathrm{BK}=$ composted pine bark, and $\mathrm{PM}=$ sphagnum peatmoss $; 0: 2: 2$

${ }^{y}$ Leachates were taken following two irrigations with water containing no fertilizer. 
Table 2. Effect of medium composition on growth and flowering response of poinsettia.

\begin{tabular}{|c|c|c|c|c|c|c|}
\hline \multicolumn{3}{|c|}{$\begin{array}{l}\text { Medium composition } \\
\text { (ratio by volume) }\end{array}$} & \multirow{2}{*}{$\begin{array}{l}\text { Plant } \\
\text { ht } \\
(\mathrm{cm})\end{array}$} & \multirow{2}{*}{$\begin{array}{l}\text { Plant } \\
\text { width } \\
(\mathrm{cm})\end{array}$} & \multirow{2}{*}{$\begin{array}{c}\text { Diam of } \\
\text { inflorescence } \\
\text { (cm) }\end{array}$} & \multirow{2}{*}{$\begin{array}{l}\text { Dry } \\
\text { wt } \\
\text { (g) }\end{array}$} \\
\hline CCB & BK & $\mathrm{PM}$ & & & & \\
\hline 1 & 3 & 0 & 25.3 & 47.7 & 29.6 & 13.8 \\
\hline 2 & 1 & 1 & 23.9 & 46.1 & 29.7 & 13.1 \\
\hline 2 & 2 & 0 & 24.2 & 46.4 & 29.2 & 11.9 \\
\hline 1 & 2 & 1 & 24.4 & 48.0 & 29.6 & 13.0 \\
\hline 0 & 2 & 2 & 27.8 & 56.8 & 32.4 & 17.1 \\
\hline $\mathrm{HSD}_{0.0 \mathrm{~s}}$ & & & 3.4 & 7.2 & 2.5 & 2.8 \\
\hline
\end{tabular}

${ }^{z} \mathrm{CCB}=$ composted cotton burrs, $\mathrm{BK}=$ composted pine bark, and $\mathrm{PM}=$ sphagnum peat; $0: 2: 2$ was the control.

Table 3. Effect of media composition" on the quality of poinsettia after exposing plants to an interior environment for 30 days.

\begin{tabular}{|c|c|c|c|c|}
\hline \multicolumn{3}{|c|}{$\begin{array}{l}\text { Medium composition } \\
\text { (ratio by volume) }\end{array}$} & \multirow{2}{*}{$\begin{array}{c}\text { Abscised } \\
\text { bracts } \\
\text { (no./plant) }\end{array}$} & \multirow{2}{*}{$\begin{array}{c}\text { No. of } \\
\text { abscised } \\
\text { leaves }\end{array}$} \\
\hline $\mathrm{CCB}$ & BK & PM & & \\
\hline 3 & 0 & 1 & 2.7 & 3.6 \\
\hline 2 & 1 & 1 & 4.1 & 2.4 \\
\hline 2 & 2 & 0 & 0.9 & 4.9 \\
\hline 1 & 2 & 1 & 2.8 & 5.9 \\
\hline 0 & 2 & 2 & 1.0 & 6.5 \\
\hline \multicolumn{3}{|c|}{$\mathrm{HSD}_{0.05}$} & NS & 3.6 \\
\hline
\end{tabular}

${ }^{\mathrm{x}} \mathrm{CCB}=$ composted cotton burrs, BK $=$ composted pine bark, and $\mathrm{PM}=$ sphagnum peat; $0: 2: 2$ was the control.

statistical programming. Tukey's honest significant difference (HSD) was used for mean comparisons.

There were substantial differences in EC among medium leachates 2 weeks after planting (Table 1). Media containing 50\% or more CCB had higher EC than media with less or no $\mathrm{CCB}$, suggesting that $\mathrm{CCB}$ either had lower cation exchange capacity or contained higher levels of soluble salts than peatmoss and bark, resulting in more nutrients or salts being carried out by the leachate. The differences in EC among media leachates declined at 8 and 11 weeks, probably a result of constant fertilizer application.

Leachates from media containing $75 \% \mathrm{CCB}$ had the highest $\mathrm{pH}(6.82)$ at 2 weeks after planting, with the others ranging between 5.9 and 6.2 (Table 1). Leachate $\mathrm{pH}$ declined between 2 and 8 weeks and changed little thereafter. The magnitude of $\mathrm{pH}$ change depended on medium composition. This result was expected since the same amount of lime was added to media that might have different buffering capacity. Leachate $\mathrm{pH}$ was more stable in media with $50 \%$ CCB. The $\mathrm{pH}$ of leachates from the medium with $50 \%$ peatmoss (control) was the lowest after 8 weeks (Table 1).

Plants produced in media amended with CCB were slightly shorter and narrower when compared to those grown in a medium with equal volumes of peatmoss and bark (Table $2)$. There was no difference in growth characteristics among plants produced in media amended with CCB. Height of poinsettia was previously found to be affected by medium composition (Blessington et al., 1981; Fonteno et al., 1981; Sanderson and Drane, 1988). 'Annette Hegg Diva' was reported to grow taller in a medium with $50 \%$ peat than in media with $25 \%$ peat (Blessington et al., 1981), consistent with the results of this study. Plant height in this study was shorter than in other reports (Blessington et al., 1981; Fonteno et al., 1981), which may be the result of late planting (15 Sept.), heavy fertilization (Nell and Barrett, 1986), cultivar difference, or environmental factors. Number of branches (5.6 to 6.0) and mean number of leaves per shoot (4.0 to 5.0) were not affected by medium composition. Media amended with $\mathrm{CCB}$ produced plants with smaller inflorescences. The wider plants produced in the medium consisting of equal volumes of bark and peatmoss may have resulted from the slightly larger inflorescences of these plants. Mean number of bracts (large, 6.0 to 6.5 ; small, 5.9 to 6.0 ) were similar, regardless of medium composition. served to show red pigmentation earlier than those in the medium without CCB, but there was no statistical difference in days to bloom (75.6 to 79.3). All plants grown in CCBamended media had similar dry weights, which were lower than the dry weights of plants produced in the medium having $50 \%$ peatmoss (Table 2). Medium with 50\% CCB and $50 \%$ bark produced plants with the lowest dry weight.

Although EC of some initial and final leachates was high (Table 1), no necrosis was observed on leaves and bracts at the end of production, which may have been due to the use of liquid fertilizer. Nell and Barrett (1985) reported that using only liquid fertilizer reduced the number of necrotic spots on leaves, compared to Osmocote applied at similar rates. More than $25 \%$ of the $\mathrm{N}$ in both fertilizers used in this study was in the nitrate form, which has previously been found to reduce leaf necrosis (Nell and Barrett, 1985).

Plant grade $(4.5-4.9 ; 1=$ poor and $5=$ excellent) after 30 days in an interior environment was unaffected by medium composition. Medium had no effect on the abscission of bracts, although the range was wide (Table 3 ). The only significant difference was in the amount of leaf abscission between the control (6.5 leaves) and plants grown in a medium containing $50 \% \mathrm{CCB}$,
Plants grown in media with CCB were ob-
$25 \%$ bark, and $25 \%$ peatmoss (2.4 leaves). However, the above difference was not visually noticeable. Most stems on plants grown in $50 \%$ peatmoss and $50 \%$ bark could not support the inflorescence and required staking to maintain the sturdiness, possibly due to their larger size. It is not clear if the low $\mathrm{pH}$ in this medium (Table 1) resulted in weak stems. Application of paclobutrazol (Wilfret, 1981) and uniconazole (Wang and Gregg, 1989) have been shown to cause weakness in stems of poinsettia and hibiscus, respectively. The greater width of these plants at the end of production (Table 2) may have been the result of weak shoots spreading out from the center.

Results of this study suggest that media with up to $75 \%$ composted cotton burrs may be used satisfactorily for producing good poinsettia plants with excellent post-production quality. Media with $50 \%$ CCB maintained acceptable levels of EC and stable $\mathrm{pH}$ during the course of this study. A minimum of $25 \%$ peatmoss is recommended to prevent a severe decline in plant dry weight.

\section{Literature Cited}

Blessington, T.M., B.L. Bequette, and E.J. Carvey. 1981. Effects of media, fertilizer and ancymidol on the growth and quality of poinsettia ( $E u$ phorbia pulcherrimaWilld. ex Koltzsch) cultivars. Mississippi Agr. \& For. Expt. Sta. Res. Rpt. vol. 6, no. 19. Mississippi State Univ., Mississippi State.

Fonteno, W.C., D.K. Cassel, and R.A. Larson. 1981. Physical properties of three container media and their effect on poinsettia growth. J. Amer. Soc. Hort. Sci. 106:736-741.

Hammer, P.A. and D.A. Bailey, 1987. Poinsettia tolerance of molybdenum. HortScience 22:12841285.

Nell, T.A. and J.E. Barrett. 1985. Nitrate-ammonium nitrogen ratio and fertilizer application method influence bract necrosis and growth of poinsettia. HortScicnce 20:1130-1131.

Nell, T.A. and J.E. Barrett. 1986. Growth and incidence of bract necrosis in 'Gutbier V-14 Glory' poinsettia. J. Amer. Soc. Hort. Sci. 111:266-269.

Sanderson, K.C. and W. Drane. 1988. Comparison of single application fertilizer programs on the growth of poinsettia in two media. HortScience 23:821. (Abstr.)

Sheehan, T.J. and B. Tjia. 1976. The effects of growing media on growth and flowering of gloxinia. Proc. Fla. State Hort. Soc. 89:319320.

Wang, Y.T. and L.L. Gregg. 1989. Uniconazole affects vegetative growth, flowering, and stem anatomy of hibiscus. J. Amer. Soc. Hort. Sci. 114:927-932.

Wang, Y.T. and J.W. Sauls. 1988. Influence of light, medium, and fertilization on growth and acclimatization of ponytail palm. HortScience 23:720-721.

Wilfret, G.J. 1981. Height retardation of poinsettia with ICI-PP-333. HortScience 16:443. (Abstr.)

Wright, R.D. 1986. The pour-through nutrient extraction procedure. HortScience 21:227-229.

Yeager, T.H., R.D. Wright, and S.S. Donohue. 1983. Comparison of pour-through and saturated pine bark extract, $\mathrm{N}, \mathrm{P}, \mathrm{K}$, and $\mathrm{pH}$ levels. J. Amer. Soc. Hort. Sci. 108:112-114. 